\title{
Article \\ ZnO Films Incorporation Study on Macroporous Silicon Structure
}

\author{
Lizeth Martínez $^{1, *}$, Godofredo García-Salgado ${ }^{2}$ (D) Francisco Morales-Morales ${ }^{3}$, Bernardo Campillo ${ }^{4,5}$, \\ Angélica G. Hernández ${ }^{1}$, Tangirala V. K. Karthik ${ }^{1}{ }^{1 D}$, María R. Jiménez-Vivanco ${ }^{2}$ and José Campos-Álvarez ${ }^{6}$ (D)
}

1 Tepeji Graduate School, Industrial Engineering, Autonomous Hidalgo State University, Av. del Maestro No. 41, Col. Noxtongo $2^{\text {a }}$ Sección, Tepeji del Rio, Hidalgo 42855, Mexico; angelica_hernandez@uaeh.edu.mx (A.G.H.); enkata_tangirala@uaeh.edu.mx (T.V.K.K.)

2 Semiconductor Devices Research Center, Autonomus University of Puebla, Ciudad Universitaria, Puebla Pue 72570, Mexico; godgarcia@yahoo.com (G.G.-S.); kasslaa@hotmail.com (M.R.J.-V.)

3 Optical Research Center, A. C., Loma del Bosque 115, Col. Lomas del Campestre, León 37150, Mexico; fcomm9@gmail.com

4 Faculty of Chemistry, Metallurgical Engineering Department, Autonomous National University of Mexico, Mexico City 04510, Mexico; bci@icf.unam.mx

5 Institute of Physical Sciences, Autonomus National University of Mexico, Cuernavaca, Morelos 62210, Mexico

6 Institute for Renewable Energy, Autonomus National University of Mexico, Priv. Xochicalco S/N, Temixco, Morelos 62580, Mexico; jca@ier.unam.mx

* Correspondence: lizeth_martinez@uaeh.edu.mx

check for updates

Citation: Martínez, L.;

García-Salgado, G.; Morales-Morales,

F.; Campillo, B.; Hernández, A.G.;

Karthik, T.V.K.; Jiménez-Vivanco,

M.R.; Campos-Álvarez, J. ZnO Films Incorporation Study on Macroporous Silicon Structure. Materials 2021, 14, 3697. https://doi.org/10.3390/ ma14133697

Academic Editor: Dokyoung Kim

Received: 1 June 2021

Accepted: 25 June 2021

Published: 1 July 2021

Publisher's Note: MDPI stays neutral with regard to jurisdictional claims in published maps and institutional affiliations.

Copyright: (C) 2021 by the authors. Licensee MDPI, Basel, Switzerland. This article is an open access article distributed under the terms and conditions of the Creative Commons Attribution (CC BY) license (https:// creativecommons.org/licenses/by/ $4.0 /)$.

\begin{abstract}
In the present work, we developed hybrid nanostructures based on $\mathrm{ZnO}$ films deposited on macroporous silicon substrates using the sol-gel spin coating and ultrasonic spray pyrolysis (USP) techniques. The changes in the growth of $\mathrm{ZnO}$ films on macroporous silicon were studied using a UV-visible spectrometer, an X-ray diffractometer (XRD), scanning electron microscopy (SEM) and atomic force microscopy (AFM). XRD analysis revealed the beneficial influence of macroporous silicon on the structural properties of $\mathrm{ZnO}$ films. SEM micrographs showed the growth and coverage of $\mathrm{ZnO}$ granular and flake-like crystals inside the pores of the substrate. The root mean square roughness (RMS) measured by AFM in the $\mathrm{ZnO}$ grown on the macroporous silicon substrate was up to one order of magnitude higher than reference samples. These results prove that the methods used in this work are effective to cover porous and obtain nano-morphologies of $\mathrm{ZnO}$. These morphologies could be useful for making highly sensitive gas sensors.
\end{abstract}

Keywords: zinc oxide; macroporous silicon; ultrasonic spray pyrolysis; spin coating; sol-gel

\section{Introduction}

At present, the effort to obtain nanostructures/hybrids from semiconducting materials has attracted considerable interest in the scientific community due to the possible superior functional properties that they could present compared to the individual components assembling composites. Among the related experimental works, zinc oxide ( $\mathrm{ZnO})$ stands out due to its morphological and physical properties. $\mathrm{ZnO}$ is a semiconductor material with a direct bandgap of $3.37 \mathrm{eV}$ at room temperature and a high excitation binding energy of $60 \mathrm{meV}$ [1]. On the other hand, $\mathrm{ZnO}$ has been recognized as a promising material for some electronic and optoelectronic applications, such as solar cells [2], transparent conductors [3,4], piezoelectric transducers [5], memristors [6], surface acoustic wave devices [7] and gas sensors [8]. In addition, $\mathrm{ZnO}$ offers distinct advantages over other metal oxides due its abundance, non-toxic nature and easy synthesis. There are different methods for $\mathrm{ZnO}$ synthesis, among which are pulsed laser deposition (PLD) [9], chemical vapor deposition (CVD) [10], the microwave [11] and hydrothermal methods [12], RF magnetron sputtering [13], the sol-gel process [14], ultrasonic spray pyrolysis (USP) [15,16] and homogeneous precipitation [17]. ZnO deposited on porous samples can present diverse 
morphologies such as nanorods [18], nanobelts [19] and nanowires [20]. The advantages of using such morphologies derive from the large surface-to-volume ratio, high specific area and surface roughness that they can present [21]. Furthermore, these $\mathrm{ZnO}$ morphologies have been used to realize sensors for various gases. These include $\mathrm{CO}_{2}, \mathrm{NO}_{2}, \mathrm{CO}, \mathrm{NH}_{3}$, $\mathrm{O}_{3}, \mathrm{H}_{2} \mathrm{~S}, \mathrm{C}_{2} \mathrm{H}_{5} \mathrm{OH}$ and $\mathrm{H}_{2}[17,21-27]$.

Among the porous nanostructures, porous silicon (PS) has a rough surface morphology which provides good sites for reducing the stress of $\mathrm{ZnO}$ growth [17]. In particular, PS has a structure with tunable pore dimensions and good compatibility with IC technology [28]. Its open structure and large surface area make PS a good candidate for templates and gas sensing applications [29]. For gas sensing applications, it is convenient to describe the sensing process as a surface mechanism in which the interactions among the sensor and gas molecules are defined by its surface area and morphology [30,31].

Recently, the detection of gases using ordered porous metal oxide nanostructures has been reported, where they can considerably facilitate gas diffusion to increase the sensing response and kinetics [30,32]. On the other hand, the incorporation of $\mathrm{ZnO}$ on macroporous silicon (mPS) is possible for enhancing the sensitivity of hybrid structure ( $\mathrm{ZnO} / \mathrm{mPS}$ ) photodetectors, and also enhancing and tuning their photoconductivity and optical properties [33]. Additionally, a non-enzymatic $\mathrm{H}_{2} \mathrm{O}_{2}$ sensor based on mPS for environmental and industrial applications has been reported, in which the surface area of the macroporous silicon structure plays an important role in the detection of $\mathrm{H}_{2} \mathrm{O}_{2}$ [34] Apart from the gas sensing application, $\mathrm{ZnO}-\mathrm{mPS}$ has been widely used for optoelectronic devices as well. Kumar et al. deposited Al-doped ZnO films on PS substrates by a RF sputtering process and demonstrated a broadening in the PL emission band, which led to white light emission [35]. $\mathrm{ZnO}$ and mPS offer high and promising properties in different fields of application.

In the effort to propose a new functional material for possible gas sensing applications, we have deposited $\mathrm{ZnO}$ films on mPS using the sol-gel spin coating and ultrasonic spray pyrolysis (USP) techniques. The effect of the $\mathrm{ZnO}$ films on the porous structure has been discussed using the optical, morphological and structural characterization techniques. The results prove that the methods used in this work are effective for covering porous and obtaining nano-morphologies of $\mathrm{ZnO}$.

\section{Materials and Methods}

\subsection{Fabrication of Macroporous Silicon Substrates}

The mPS samples were fabricated using p-type boron-doped crystalline silicon (cSi) wafers, in (100) orientation with a resistivity of $1-20 \Omega \cdot \mathrm{cm}$. The anodization process was carried out in $1.5 \mathrm{~cm} \times 1.5 \mathrm{~cm}$ wafers, using an electrolyte based on hydrofluoric acid (Meyer, 48 wt.\%) [HF] and dimethylformamide (Fermont, 99.9\%) [DMF: $\left.\mathrm{HCON}\left(\mathrm{CH}_{3}\right)_{2}\right]$ in a volumetric ratio of $1: 3$. The porous structure was fabricated by applying a current density of $\mathrm{J}=10 \mathrm{~mA} / \mathrm{cm}^{2}$ for $10 \mathrm{~min}$. The $\mathrm{mPS}$ samples were oxidized at $400{ }^{\circ} \mathrm{C}$ for $30 \mathrm{~min}$ to stabilize the porous silicon surface.

\subsection{Deposition of ZnO Thin Films by the Sol-Gel Spin Coating Method}

The deposition of $\mathrm{ZnO}$ films by sol-gel spin coating method consisted of two stages: (1) synthesis of $\mathrm{ZnO}$ precursor solution by sol-gel method, and (2) deposition of the $\mathrm{ZnO}$ precursor solution using the spin coating technique. In the first stage, $0.2 \mathrm{M}$ of dihydrated zinc acetate $\left(98.0-100 \%\right.$, Alfa Aesar) $\left[\mathrm{Zn}\left(\mathrm{CH}_{3} \mathrm{COO}\right)_{2} \cdot 2 \mathrm{H}_{2} \mathrm{O}\right]$ was dissolved in $50 \mathrm{~mL}$ ethanol (99.7\%, Fermont) $\left[\mathrm{C}_{2} \mathrm{H}_{5} \mathrm{OH}\right]$, and kept under magnetic stirring for $1 \mathrm{~h}$. Later, monoethanolamine (99\%, Meyer) [MEA: $\mathrm{HOCH}_{2} \mathrm{CH}_{2} \mathrm{NH}_{2}$ ] was added in a 1:1 molar ratio during stirring and kept there for $1 \mathrm{~h}$, until a clear solution was obtained. Finally, dihydrated MEA/zinc acetate was kept in an ultrasonic bath (Mikel's, TLU-3) at $50{ }^{\circ} \mathrm{C}$ for an hour and subsequently left at room temperature for $48 \mathrm{~h}$ for hydrolysis [35].

In the second stage, mPS substrates were immersed in the previously prepared solution and kept in an ultrasonic bath (Mikel's, TLU-3) for 30 s. Subsequently, ZnO ex- 
cess was removed and distributed on the mPS surface using the spin coating method (Laurell, WS-650-23) at $3000 \mathrm{rpm}$ for $30 \mathrm{~s}$. In order to remove the organic solvents of the samples, the substrates were heated and dried on a hot plate at $100{ }^{\circ} \mathrm{C}$ for $5 \mathrm{~min}$. The above process was repeated seven times to cover the mPS. Finally, the samples were subjected to heat treatment (ARSA, AR-340) at $400{ }^{\circ} \mathrm{C}$ for $30 \mathrm{~min}$.

\subsection{Deposition of ZnO Thin Films by the USP Method}

This deposition method consisted in the preparation of the $\mathrm{ZnO}$ precursor solution, in which $0.2 \mathrm{M}$ of zinc acetate dihydrate ( $\geq 98 \%$, Alfa Aesar) $\left[\mathrm{Zn}\left(\mathrm{CH}_{3} \mathrm{COO}\right)_{2} \cdot 2 \mathrm{H}_{2} \mathrm{O}\right]$ was diluted in $50 \mathrm{~mL}$ ethanol $\left(99.7 \%\right.$, Fermont) $\left[\mathrm{C}_{2} \mathrm{H}_{5} \mathrm{OH}\right]$ and kept under magnetic stirring for $1 \mathrm{~h}$ at room temperature. During deposition the substrate temperature was kept at $260{ }^{\circ} \mathrm{C} \pm 3{ }^{\circ} \mathrm{C}$ for $10 \mathrm{~min}$. The pressure and carrier gas flow $\left(\mathrm{N}_{2}\right)$ were maintained at $276 \mathrm{kPa}$ and $0.09 \mathrm{~L} / \mathrm{min}$, respectively [36]. Finally, the samples were subjected to heat treatment (ARSA, AR-340) at $400{ }^{\circ} \mathrm{C}$ for $30 \mathrm{~min}$. To obtain the control samples, the deposition processes were carried out on glass substrates of $1.5 \mathrm{~cm} \times 1.5 \mathrm{~cm}$. Table 1 shows the names of the prepared samples.

Table 1. Summary of samples fabricated.

\begin{tabular}{cc}
\hline Sample & Characteristics \\
\hline Z1G & ZnO on glass substrate by sol-gel spin coating method \\
Z1P & ZnO on mPS substrate by sol-gel spin coating method \\
Z2G & ZnO on glass substrate by USP method \\
Z2P & ZnO on mPS substrate by USP method \\
\hline
\end{tabular}

\subsection{Characterization of $\mathrm{ZnO}$ Thin Films}

The optical transmittance of the $\mathrm{ZnO}$ films deposited on glass substrates was analyzed using a UV-Vis spectrometer (VE-5100UV, VELAB, CDMX, México). The structural properties of the $\mathrm{ZnO}$ films deposited on glass and mPS substrates were investigated by an X-ray diffractometer (XRD) (AXS D8 Discover, Bruker, Karlsruhe, Germany) employing $\mathrm{CuK} \alpha$ radiation and $\lambda=1.54 \AA$. The morphological surface and topography were analyzed with scanning electron microscopy (SEM) (JEOL JSM 7401F, Hitachi High-Tech Canada. Inc., Toronto, Ontario, Canada) and an atomic force microscope (AFM) (Park NX10, Park Systems Inc., Suwon, Corea). AFM measurements were conducted at room temperature in non-contact mode. The cantilever was made out of silicon with a spring constant of $42 \mathrm{~N} / \mathrm{m}$ and a nominal tip apex radius of $10 \mathrm{~nm}$. Measurements were performed for a scan size of $10 \times 10 \mu \mathrm{m}^{2}$ with a resolution of $256 \times 256$ pixels. The analysis of AFM measurements was analyzed with the help of the XEI program.

\section{Results and Discussion}

In order to check the quality of the $\mathrm{ZnO}$ films, the transmittance was measured in the range 350-750 $\mathrm{nm}$. Figure 1 shows the optical transmittance, bandgap and cross-sectional SEM images of ZnO films deposited on glass substrates (Z1G) by the sol-gel spin coating and USP (Z2G) techniques. The transmittance spectrum of the $\mathrm{ZnO}$ films (Figure 1a) showed an optical average transparency over $84 \%$ in the visible range and an accentuation in the region of $360 \mathrm{~nm}$ (Z1G) and $370 \mathrm{~nm}$ (Z2G) corresponding to sol-gel spin coating and USP deposition, respectively. The sharp ultraviolet absorption edges of the samples at a wavelength close to 360-370 $\mathrm{nm}$ corresponds to the intrinsic bandgap energy of $\mathrm{ZnO}[35,37]$. The decrease in the average transparency can be attributed to irregularities in the grain boundaries of $\mathrm{ZnO}$ and scattering due to surface roughness [38]. About $80 \%$ transparency in $\mathrm{ZnO}$ films has been reported to be sufficient for optoelectronic applications [39]. Furthermore, Mirela Suchea et al. studied ZnO transparent films deposited on cSi and glass substrates and found that the gas sensing characteristics of the $\mathrm{ZnO}$ films were highly influenced by surface morphology [40]. 

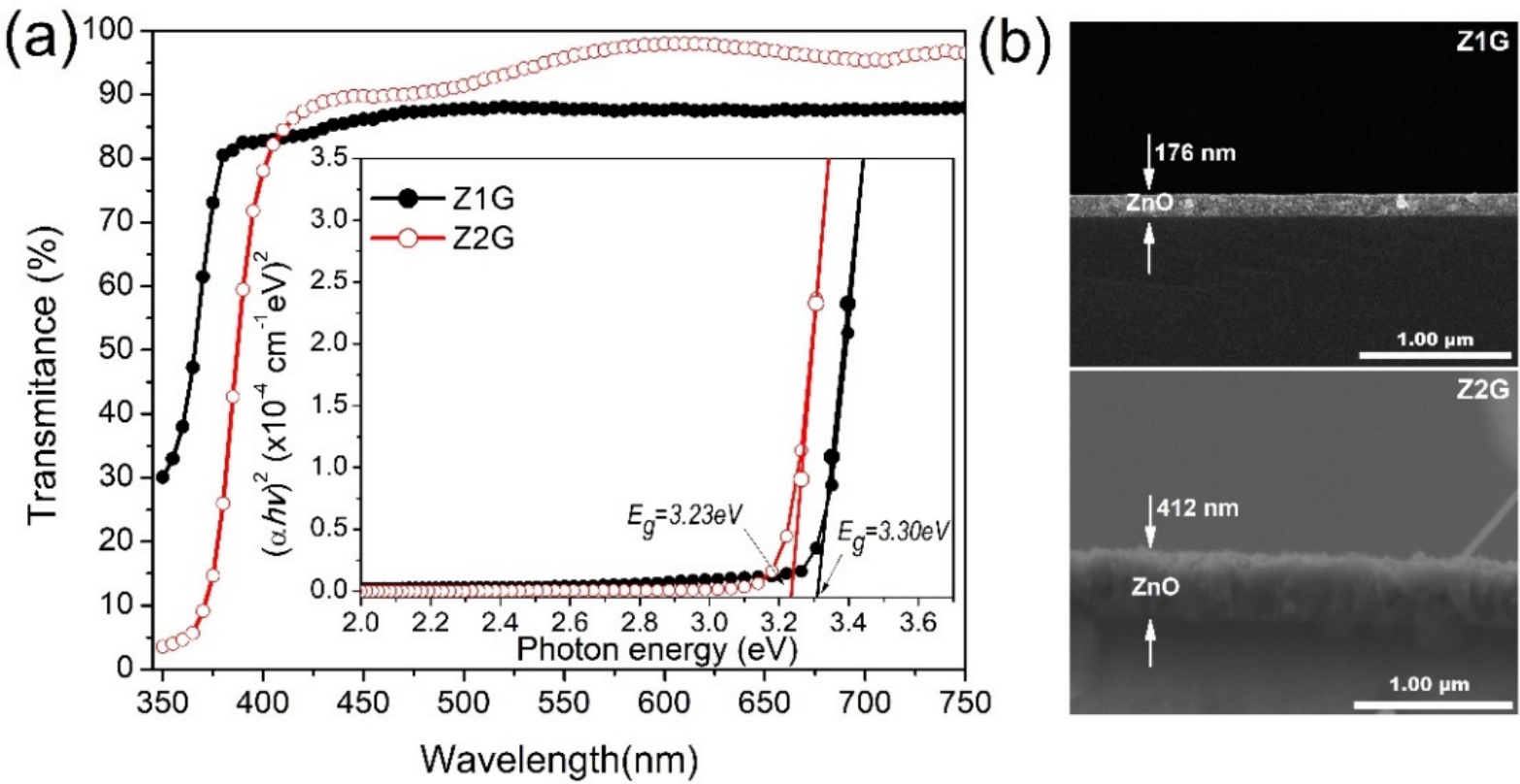

Figure 1. (a) Optical transmittance and band gap properties; and (b) cross-sectional SEM images of ZnO films deposited on corning glass by sol-gel spin coating (Z1G) and USP (Z2P) methods.

From the experimental transmittance spectra of $\mathrm{ZnO}$ films, which have an average thickness (Figure 1b) of $176 \mathrm{~nm}(\mathrm{Z1G})$ and $412 \mathrm{~nm}(\mathrm{Z} 2 \mathrm{G})$, the absorption coefficient $(\alpha)$ and its relation to the bandgap $(\mathrm{Eg})$ were determined using the equation $\alpha \mathrm{hv}=\mathrm{A}(\mathrm{hv}-\mathrm{Eg})^{1 / 2}$, where $\mathrm{A}$ is the constant, Eg is the optical bandgap, $\mathrm{v}$ is the incident radiation frequency and finally $\mathrm{h}$ is Planck's constant [41,42]. Inside Figure $1 \mathrm{a}$, we can see the Tauc plot $(\alpha \mathrm{hv})^{2}$ vs. photon energy (hv). The Eg value of $\mathrm{ZnO}$ film was obtained by extrapolating the straight line portion of plot to zero absorption coefficient. The bandgap of $\mathrm{ZnO}$ film was found to be $\mathrm{Eg}=3.30 \mathrm{eV}$ for sol-gel spin coating $(\mathrm{Z1G})$ and $\mathrm{Eg}=3.23 \mathrm{eV}$ for USP $(\mathrm{Z} 2 \mathrm{G})$ technique, respectively. The $\mathrm{Eg}$ values obtained are similar to bulk $\mathrm{ZnO}$, which reveals the good quality and impurity-free nature of $\mathrm{ZnO}$ films prepared by sol-gel spin coating and USP $[43,44]$.

The crystallinity of $\mathrm{ZnO}$ films on mPS was investigated using the XRD technique. Figure 2 shows the $\mathrm{XRD}$ patterns of $\mathrm{ZnO}$ films deposited on glass and $\mathrm{mPS}$ substrate by the sol-gel spin coating (Z1G, Z1P) and USP methods (Z2G, Z2P), respectively.
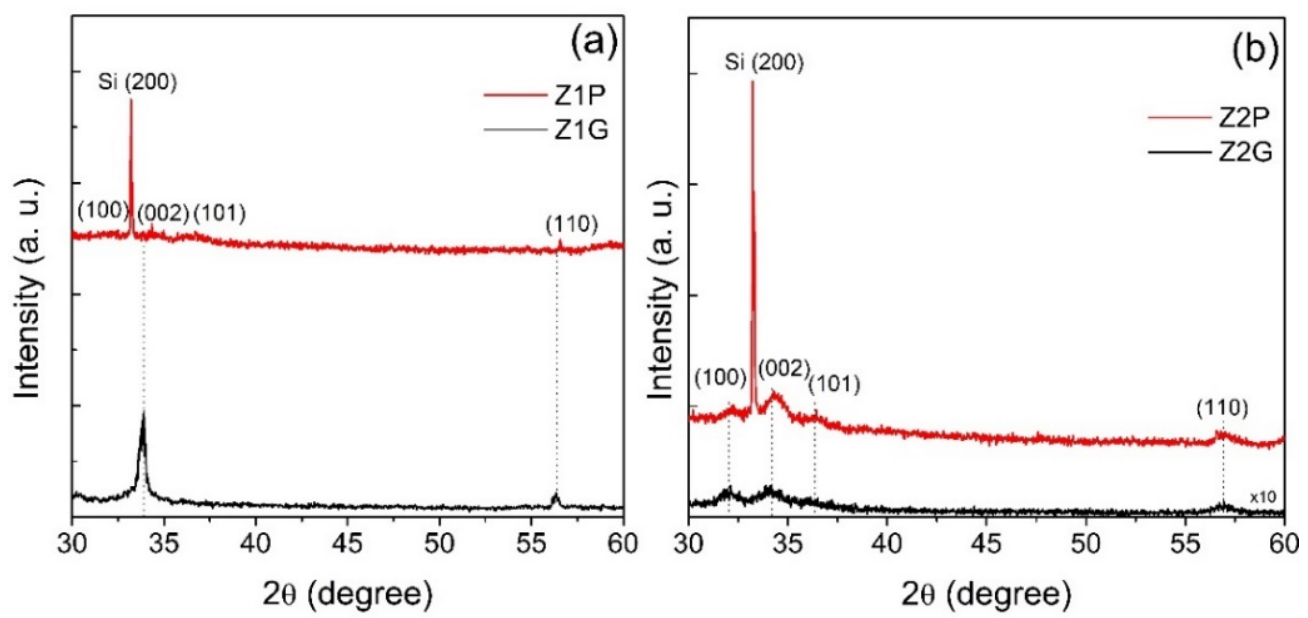

Figure 2. XRD patterns of ZnO films deposited by the sol-gel spin coating (a) and USP (b) methods on glass (Z1G, Z2G) and macroporous silicon (Z1P, Z2P) substrate. 
The XRD spectra showed the presence of (100), (002), (101) and (110) peaks, demonstrating that the samples Z1P and Z2P were polycrystalline (Joint Committee for Powder Diffraction Studies (JDPS) No. 36-1451) [10]. The diffractograms also show the presence of a (200) peak in the ZnO films deposited on mPS (Z1P, Z2P), indicating the presence of silicon ( $\mathrm{Si}$ ) in the substrate [45]. It can be seen that the most samples have a second maximum diffraction peak along the (002) plane. The above demonstrates that the $\mathrm{ZnO}$ films crystallized in the wurtzite phase of the hexagonal structure with a preferential orientation towards the c-axis, which is perpendicular to the substrate surface [46]. The $\mathrm{c}$-axis orientation corresponds to the densest plane and means that the $\mathrm{ZnO}$ films have piezoelectric properties [47]. Gonzalo Alonso Velázquez-Nevárez et al. corroborated that the $\mathrm{ZnO}$ films with orientation (002) grown at $400{ }^{\circ} \mathrm{C}$ were the most appropriate to achieve lowest resistivity $(7.1 \Omega \cdot \mathrm{cm})$. They suggested that appropriate annealing temperature to achieve smallest resistivity was $400{ }^{\circ} \mathrm{C}$, which may have been related to the high amount of oxygen vacancies [48]. In addition, F. Fitriana et al. found that (002)-oriented $\mathrm{ZnO}$ has high potential for a highly sensitive $\mathrm{CO}$ and NO sensor [49].

The average crystalline size (D) and the strain-induced broadening $(\varepsilon)$ of $\mathrm{ZnO}$ films were calculated from $X$-ray diffraction using the Scherrer equation and the Williamson-Hall method (W-H) $[50,51]$. According to Williamson and Hall, diffraction broadening is due to crystallite and strain contribution [52]. The strain-induced broadening of $\mathrm{ZnO}$ films was calculated using the formula $\varepsilon=\beta / 4 \tan \theta$; where $\beta$ is the full-width half-maximum (FWHM) [51]. The values are shown in Table 2. The crystallite sizes for Z1G and Z1P were $20 \mathrm{~nm}$ and $15 \mathrm{~nm}$, respectively. The decrease in the crystal size from Z1G to Z1P indicates an improvement crystallization of $\mathrm{ZnO}$ films when they are deposited on $\mathrm{mPS}$. We can observe that the opposite occurs for Z2G and Z2P samples. The crystallite size from $Z 2 G$ to $Z 2 P$ was $6 \mathrm{~nm}$ to $8 \mathrm{~nm}$, respectively. The increase in crystal size could be due to the deposition process not allowing time to connect small nanocrystals on the porous substrates. These results have been corroborated by the reports of Hong Cai et al. [53] and Tae-Bong Hur et al. [54]. They attributed the increase in crystal size to a decrease in strain and the skeleton of porous silicon, in which the steady-state regime relaxes stress [53,54].

Table 2. Summary of structural parameters of $\mathrm{ZnO}$ thin films deposited on glass and mPS substrates by sol-gel spin coating and USP methods.

\begin{tabular}{ccccc}
\hline Sample & FWHM (002) & $\left.\mathbf{2} \boldsymbol{\theta} \mathbf{(}^{\circ}\right)$ & Crystallite Size $(\mathbf{n m})$ & $\varepsilon$ \\
\hline Z1G & 0.4213 & 33.8145 & 20 & 0.100826 \\
Z1P & 0.5312 & 34.4291 & 15 & 0.126851 \\
\hline Z2G & 1.3099 & 34.0601 & 6 & 0.313116 \\
Z2P & 0.9811 & 34.4287 & 8 & 0.234288 \\
\hline
\end{tabular}

The role of the substrate is very important to limit the direction and rate growth of $\mathrm{ZnO}$ films [18]. However, the crystallite size could be also influenced by various factors such as impurities, defects, temperature and synthesis environment conditions [55,56]. That may be the reason why the values data are scattered and there is present a trend of decreasing crystallite size when the FWHM increases.

The SEM images were obtained in order to study the porous substrate effect and the deposition method's influence on ZnO films morphology. Figure 3 shows the top (left side) and cross sectional (right side) micrographs of the samples. The bare mPS substrate is shown in Figure 3a,b. These micrographs reveal the mPS substrate morphology displaying an irregular distribution of round pores of $\sim 1 \mu \mathrm{m}$ diameter (Figure 3a). The cross-sectional image of the mPS substrate shown in Figure $3 b$ corroborates the pore diameter and the mPS film thickness at $\sim 2 \mu \mathrm{m}$.

In Figure 3c,d, we can see the $\mathrm{ZnO}$ films deposited on the mPS substrate by the sol-gel spin coating method (Z1P). The top-sectional image shown in Figure $3 c, d$ reveals the completely decorated pore presenting the formation of granular $\mathrm{ZnO}$ films on the entire surface of the mPS substrate. In addition, the fracture of some pores can be observed, 
which surely could have been caused by sonication during the $\mathrm{ZnO}$ deposition process. In Figure 3e,f, we have observed the ZnO deposited on mPS substrate by USP method deposition (Z2P). We found that $\mathrm{ZnO}$ films exhibit a dense structure covering the mPS surface. Figure 4 shows the SEM magnification of $\mathrm{ZnO}$ deposited on mPS substrates (Z1P, Z2P).
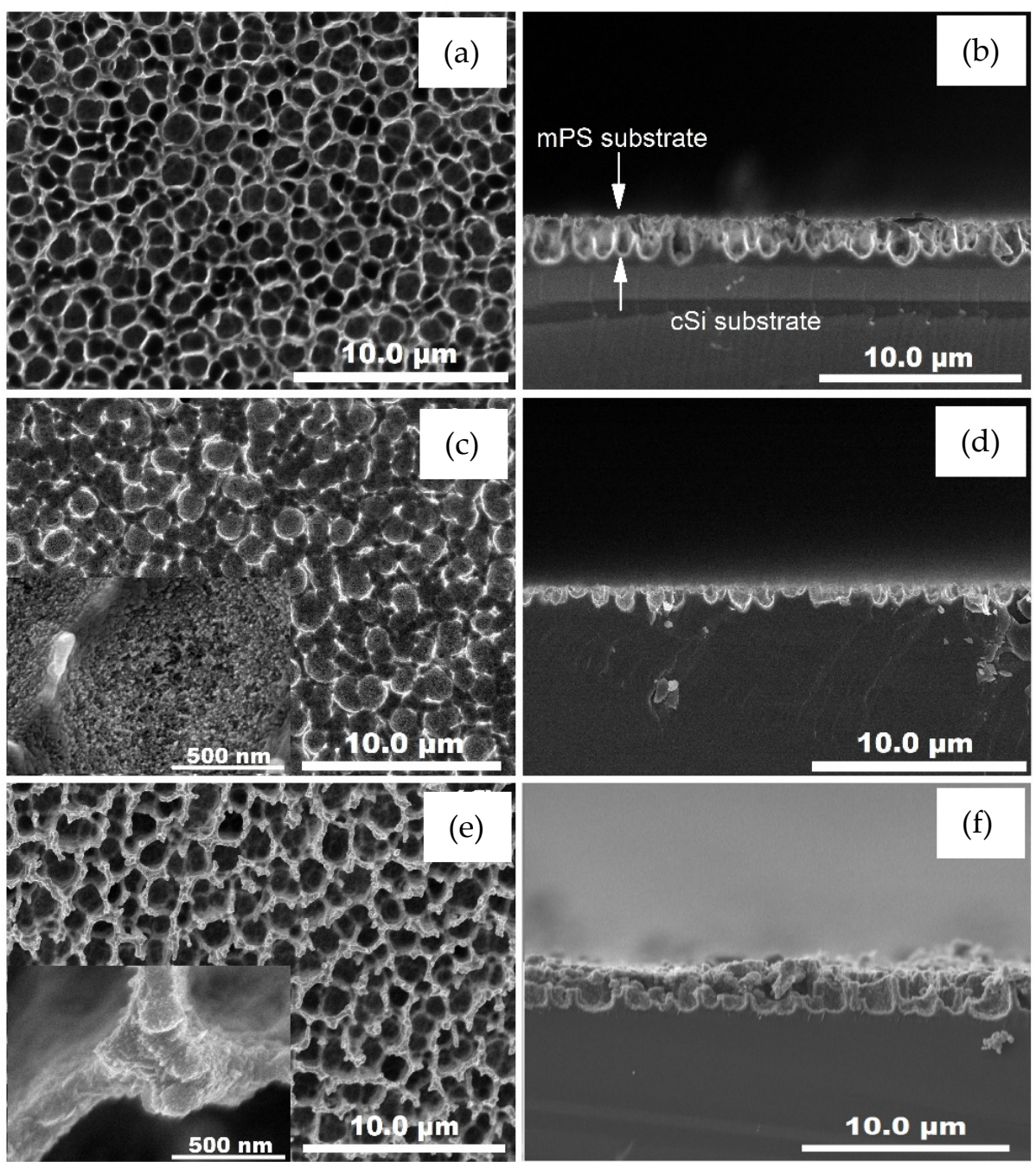

Figure 3. SEM micrographs of the top (left side) and cross (right side) sectional of bare mPS substrate $(\mathbf{a}, \mathbf{b})$; ZnO films deposited on mPS by sol-gel spin coating Z1P (c,d), and USP, Z2P (e,f) methods.
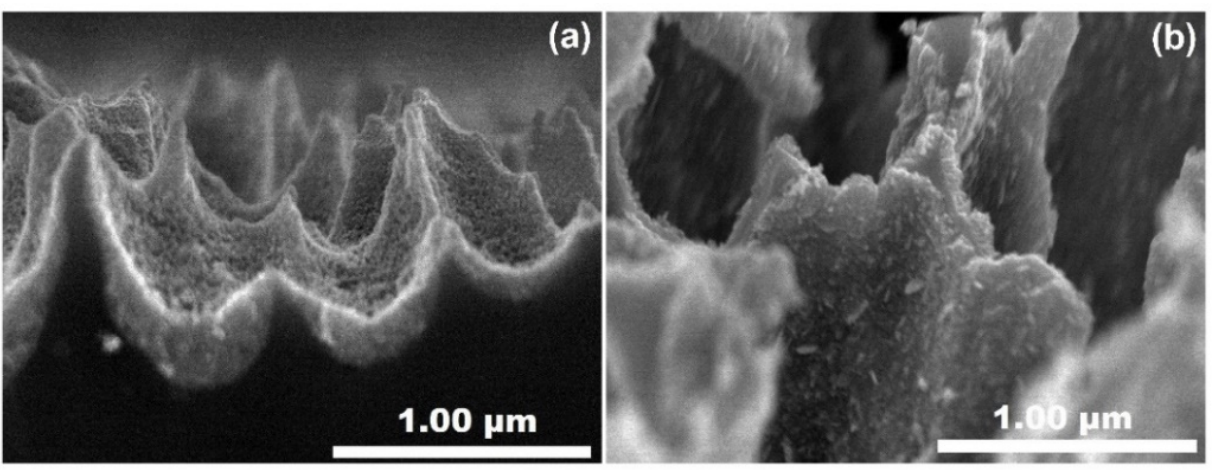

Figure 4. SEM micrographs of cross-sectional images with higher magnifications corresponding to Z1P (a) and Z2P (b). 
Figure 4a shows the infiltration of $\mathrm{ZnO}$ films inside the pore; in this way, we can confirm the $\mathrm{ZnO}^{\prime}$ s granular shape and the connectivity of nanocrystals covering the pore. The crystal connectivity enhances the bonds existing in the $\mathrm{ZnO}$ films, which are favorable for adsorption of gas molecular [57]. Figure $4 \mathrm{~b}$ shows the $\mathrm{ZnO}$ films deposited on mPS structure by the USP method. We found that small flake-like nanocrystals grew on the macroporous silicon skeleton in vertical form, so that the XRD (002) diffraction peak increased somewhat (Figure 2b). These flake-like crystals could have been formed due to the porous silicon substrates providing nucleation centers for initial formation and the free energy at nanometric scale inducing the $\mathrm{ZnO}$ crystal growth [13,58-60]. SEM micrographs gave us proof that the methods used in this work are effective for covering porous and obtaining nano-morphologies of $\mathrm{ZnO}$.

Figure 5 shows the two dimensional AFM images taken at a scan area of $10 \times 10 \mu \mathrm{m}^{2}$ (a) and the comparison of depth profiles (b) of $\mathrm{ZnO}$ deposited via sol-gel spin coating (Z1G, Z1P) and USP (Z2G, Z2P) techniques. Figure $5 \mathrm{~b}$ shows the longitudinal increase in waviness in the $\mathrm{ZnO}-\mathrm{mPS}$ surface profile is higher than $\mathrm{ZnO}-$ glass samples. The roughness mean square (RMS) values from the $\mathrm{ZnO}$ films deposited on glass substrates were $16 \mathrm{~nm}$ $(\mathrm{Z1G})$ and $10 \mathrm{~nm}(\mathrm{Z} 2 \mathrm{G})$. The above results are similar to other reports related to surface roughness studies by AFM [61,62]. RMS values from $\mathrm{ZnO}$ films deposited on mPS were $244 \mathrm{~nm}(\mathrm{Z1P})$ and $194 \mathrm{~nm}(\mathrm{Z} 2 \mathrm{P})$, respectively. Such results show that ZnO deposited on mPS increased the roughness surface up to one order of magnitude compared to the $\mathrm{ZnO}$ deposited on glass substrates. These results strengthen earlier studies by U. SalazarKuri et al. and confirm the increase in surface roughness of $\mathrm{ZnO}$ deposited on mPS [63]. From the SEM and AFM results above, it can be seen that the MPS substrate can be used as a good template to increase the surface roughness of $\mathrm{ZnO}$ films; in addition, its porous structure can improve the growth of $\mathrm{ZnO}$.

(a)
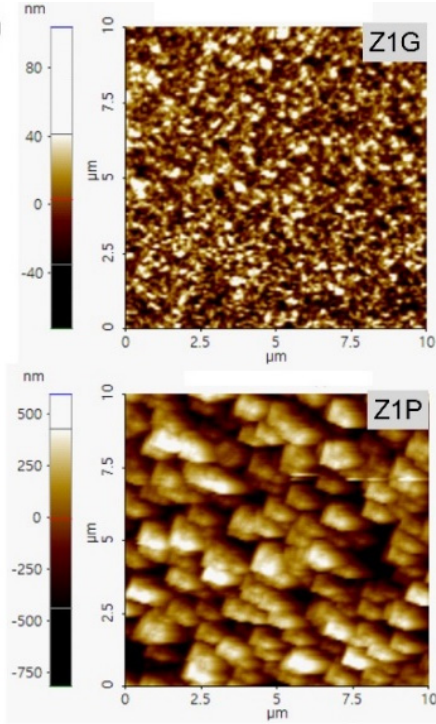

(b)
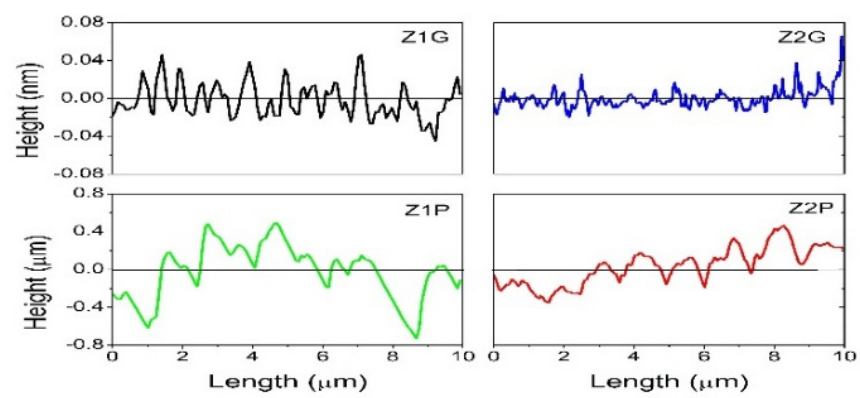

Figure 5. Atomic force microscopy images (a) and height profile (b) of $\mathrm{ZnO}$ deposited by sol-gel spin coating (Z1G, Z1P) and USP (Z2G, Z2P) techniques. 


\section{Conclusions}

In this paper, it was possible to deposit $\mathrm{ZnO}$ films on mPS substrates by the sol-gel spin coating and USP methods. The ZnO pore decoration of mPS substrates revealed the formation of granular nanocrystals for the sol-gel spin-coating method and flake-like crystals for the USP method. The crystal size and shape were described in terms of straininduced broadening and the influence of mPS. The roughness surface of the $\mathrm{ZnO}$ films on mPS substrates increased up to one order of magnitude compared to the $\mathrm{ZnO}$ deposited on glass substrates. SEM and AFM analysis confirmed that the mPS substrate can function as a good template for increasing the $\mathrm{ZnO}$ surface roughness and as a template for $\mathrm{ZnO}$ crystal growth. This study can lead the way to more extensive studies of the employment of $\mathrm{ZnO}$ with a mPS structure in the sensors field, including gas sensors and biosensors as well as the sensing of different substances as ethanol, drugs and explosives.

Author Contributions: Conceptualization, methodology, supervision, L.M. and G.G.-S.; Validation, investigation, L.M., G.G.-S. and F.M.-M.; Data curation, formal analysis, F.M.-M., B.C., M.R.J.-V. and J.C.-Á.; Writing-original draft preparation, L.M. and G.G.-S.; Resources, administration, L.M., A.G.H. and T.V.K.K. All authors have read and agreed to the published version of the manuscript.

Funding: This research received no external funding.

Institutional Review Board Statement: Not applicable.

Informed Consent Statement: Not applicable.

Data Availability Statement: Not applicable.

Acknowledgments: This work has been supported by PRODEP, project No. 511-6/19-8268. We acknowledge the help provided by Rafael Iván Puente Lee (USAI, FQ-UNAM) in acquiring the AFM micrographs. L.M. acknowledges discussions with Maraolina Dominguez-Díaz.

Conflicts of Interest: The authors declare no conflict of interest.

\section{References}

1. Djurišić, A.B.; Chen, X.; Leung, Y.H.; Ng, A.M.C. ZnO nanostructures: Growth, properties and applications. J. Mater. Chem. 2012, 22, 6526. [CrossRef]

2. Son, D.-Y.; Im, J.-H.; Kim, H.-S.; Park, N.-G. 11\% Efficient Perovskite Solar Cell Based on ZnO Nanorods: An Effective Charge Collection System. J. Phys. Chem. C 2014, 118, 16567-16573. [CrossRef]

3. Li, Y.; Men, Y.; Kong, X.; Gao, Z.; Han, L.; Li, X. Enhanced electrical properties of ZnO transparent conducting films prepared by electron beam annealing. Appl. Surf. Sci. 2018, 428, 191-198. [CrossRef]

4. Liu, X.; Pan, K.; Li, W.; Hu, D.; Liu, S.; Wang, Y. Optical and gas sensing properties of Al-doped ZnO transparent conducting films prepared by sol-gel method under different heat treatments. Ceram. Int. 2014, 40, 9931-9939. [CrossRef]

5. Pan, M.-C.; Wu, T.-H.; Bui, T.-A.; Shih, W.-C. Fabrication of highly c-axis textured ZnO thin films piezoelectric transducers by RF sputtering. J. Mater. Sci. Mater. Electron. 2012, 23, 418-424. [CrossRef]

6. Panda, D.; Simanjuntak, F.M.; Chandrasekaran, S.; Pattanayak, B.; Singh, P.; Tseng, T.-Y. Barrier Layer Induced Switching Stability in Ga:ZnO Nanorods Based Electrochemical Metallization Memory. IEEE Trans. Nanotechnol. 2020, 19, 764-768. [CrossRef]

7. Zhou, J.; Tao, X.; Luo, J.; Li, Y.; Jin, H.; Dong, S.; Luo, J.; Duan, H.; Fu, Y. Nebulization using ZnO/Si surface acoustic wave devices with focused interdigitated transducers. Surf. Coat. Technol. 2019, 367, 127-134. [CrossRef]

8. Zhu, L.; Zeng, W. Room-temperature gas sensing of ZnO-based gas sensor: A review. Sens. Actuators A Phys. 2017, 267, $242-261$. [CrossRef]

9. Aydemir, G.; Utlu, G.; Çetinel, A. Growth and characterization of ZnO nanostructures on porous silicon substrates: Effect of solution temperature. Chem. Phys. Lett. 2019, 737, 136827. [CrossRef]

10. Ali, G.G.; Sulaiman, A.K.A.; Karomi, I.B. The effect of the ZnO thickness layer on the porous silicon properties deposited by chemical vapor deposition. AIP Conf. Proc. 2018, 2034, 020009. [CrossRef]

11. Wojnarowicz, J.; Chudoba, T.; Lojkowski, W. A Review of Microwave Synthesis of Zinc Oxide Nanomaterials: Reactants, Process Parameters and Morphologies. Nanomaterials 2020, 10, 1086. [CrossRef]

12. Eswar, K.A.; Rouhi, J.; Husairi, F.; Dalvand, R.; Alrokayan, S.A.; Khan, H.A.; Mahmood, M.R.; Abdullah, S. Hydrothermal growth of flower-like $\mathrm{ZnO}$ nanostructures on porous silicon substrate. J. Mol. Struct. 2014, 1074, 140-143. [CrossRef]

13. Martínez, L.; Holguín-Momaca, J.; Karthik, T.; Olive-Méndez, S.; Campos-Alvarez, J.; Agarwal, V. Sputtering temperature dependent growth kinetics and $\mathrm{CO} 2$ sensing properties of $\mathrm{ZnO}$ deposited over porous silicon. Superlattices Microstruct. 2016, 98, 8-17. [CrossRef] 
14. Znaidi, L.; Chauveau, T.; Tallaire, A.; Liu, F.; Rahmani, M.; Bockelee, V.; Vrel, D.; Doppelt, P. Textured ZnO thin films by sol-gel process: Synthesis and characterizations. Thin Solid Films 2016, 617, 156-160. [CrossRef]

15. Flores, G.; Carrillo, J.; Luna, J.; Martinez, R.M.; Sierra-Fernandez, A.; Milosevic, O.; Rabanal, M. Synthesis, characterization and photocatalytic properties of nanostructured $\mathrm{ZnO}$ particles obtained by low temperature air-assisted-USP. Adv. Powder Technol. 2014, 25, 1435-1441. [CrossRef]

16. Nayef, U.M.; Muayad, M.W.; Khalaf, H.A. Effect of ZnO layers on Porous silicon properties. Int. J. Electrochem. Sci. 2014, 9, 2278-2284.

17. Karthik, T.; Martinez, L.; Agarwal, V. Porous silicon ZnO/SnO2 structures for CO2 detection. J. Alloy. Compd. 2018, 731, 853-863. [CrossRef]

18. Shabannia, R. Vertically aligned ZnO nanorods on porous silicon substrates: Effect of growth time. Prog. Nat. Sci. 2015, 25, 95-100. [CrossRef]

19. Kaur, M.; Kailasaganapathi, S.; Ramgir, N.; Datta, N.; Kumar, S.; Debnath, A.; Aswal, D.; Gupta, S. Gas dependent sensing mechanism in ZnO nanobelt sensor. Appl. Surf. Sci. 2017, 394, 258-266. [CrossRef]

20. Zhang, Y.; Ram, M.; Stefanakos, E.K.; Goswami, D.Y. Synthesis, Characterization, and Applications of ZnO Nanowires. J. Nanomater. 2012, 2012, 1-22. [CrossRef]

21. Zhang, J.; Liu, X.; Neri, G.; Pinna, N. Nanostructured Materials for Room-Temperature Gas Sensors. Adv. Mater. 2016, 28 , 795-831. [CrossRef] [PubMed]

22. Paliwal, A.; Sharma, A.; Tomar, M.; Gupta, V. Carbon monoxide (CO) optical gas sensor based on ZnO thin films. Sens. Actuators B Chem. 2017, 250, 679-685. [CrossRef]

23. Li, C.-F.; Hsu, C.-Y.; Li, Y.-Y. NH3 sensing properties of ZnO thin films prepared via sol-gel method. J. Alloy. Compd. 2014, 606, 27-31. [CrossRef]

24. Colmenares, N.; Correr, W.; Mastelaro, V.R. Deposition Rate Influence in O3 Sensing Response of Sputtered ZnO Thin Films. Proceedings 2017, 1, 429. [CrossRef]

25. Shinde, S.D.; Patil, G.; Kajale, D.; Gaikwad, V.; Jain, G. Synthesis of ZnO nanorods by spray pyrolysis for H2S gas sensor. J. Alloy. Compd. 2012, 528, 109-114. [CrossRef]

26. Ramgir, N.S.; Kaur, M.; Sharma, P.K.; Datta, N.; Kailasaganapathi, S.; Bhattacharya, S.; Debnath, A.; Aswal, D.; Gupta, S. Ethanol sensing properties of pure and Au modified ZnO nanowires. Sens. Actuators B Chem. 2013, 187, 313-318. [CrossRef]

27. Cheng, I.-K.; Lin, C.-Y.; Pan, F.-M. Gas sensing behavior of $\mathrm{ZnO}$ toward $\mathrm{H} 2$ at temperatures below $300{ }^{\circ} \mathrm{C}$ and its dependence on humidity and Pt-decoration. Appl. Surf. Sci. 2021, 541, 148551. [CrossRef]

28. Kumar, Y.; Herrera-Zaldivar, M.; Singh, F.; Olive-Méndez, S.F.; Kanjilal, D.; Kumar, S.; Agarwal, V. Cathodoluminescence and photoluminescence of swift ion irradiation modified zinc oxide-porous silicon nanocomposite. Mater. Sci. Eng. B 2012, 177, 1476-1481. [CrossRef]

29. Mizsei, J. Gas sensor applications of porous Si layers. Thin Solid Films 2007, 515, 8310-8315. [CrossRef]

30. Singh, P.; Simanjuntak, F.M.; Wu, Y.-C.; Kumar, A.; Zan, H.-W.; Tseng, T.-Y. Sensing performance of gas sensors fabricated from controllably grown ZnO-based nanorods on seed layers. J. Mater. Sci. 2020, 55, 8850-8860. [CrossRef]

31. Leonardi, S.G. Two-Dimensional Zinc Oxide Nanostructures for Gas Sensor Applications. Chemosensors 2017, 5, 17. [CrossRef]

32. Ureña, F.; Olsen, S.H.; Escobedo-Cousin, E.; Minamisawa, R.A.; Raskin, J.-P. Roughness analysis in strained silicon-on-insulator wires and films. J. Appl. Phys. 2014, 116, 124503. [CrossRef]

33. Rosli, N.; Halim, M.M.; Chahrour, K.M.; Hashim, R. Incorporation of Zinc Oxide on Macroporous Silicon Enhanced the Sensitivity of Macroporous Silicon MSM Photodetector. ECS J. Solid State Sci. Technol. 2020, 9, 105005. [CrossRef]

34. Al-Hardan, N.H.; Hamid, M.A.A.; Shamsudin, R.; Al-Khalqi, E.M.; Keng, L.K.; Ahmed, N.M. Electrochemical Hydrogen Peroxide Sensor Based on Macroporous Silicon. Sensors 2018, 18, 716. [CrossRef] [PubMed]

35. Li, Y.; Xu, L.; Li, X.; Shen, X.; Wang, A. Effect of aging time of ZnO sol on the structural and optical properties of ZnO thin films prepared by sol-gel method. Appl. Surf. Sci. 2010, 256, 4543-4547. [CrossRef]

36. Tangirala, V.K.; Vargas, I.R.; Zanabria, A.G.H.; Martínez-Ayala, L.; Ruíz, H.D.M. Diseño y fabricación del equipo de rocío químico asistido por ultra sonicación. TEPEXI Boletín Científico de la Escuela Superior Tepeji del Río 2019, 6, 14-19. [CrossRef]

37. Bedia, A.; Bedia, F.Z.; Aillerie, M.; Maloufi, N.; Benyoucef, B. Influence of the Thickness on Optical Properties of Sprayed ZnO Hole-blocking Layers Dedicated to Inverted Organic Solar Cells. Energy Procedia 2014, 50, 603-609. [CrossRef]

38. Gadallah, A.-S.; El-Nahass, M.M. Structural, Optical Constants and Photoluminescence of ZnO Thin Films Grown by Sol-Gel Spin Coating. Adv. Condens. Matter Phys. 2013, 2013, 1-11. [CrossRef]

39. Begum, N.J.; Ravichandran, K. Effect of source material on the transparent conducting properties of sprayed ZnO:Al thin films for solar cell applications. J. Phys. Chem. Solids 2013, 74, 841-848. [CrossRef]

40. Suchea, M.; Christoulakis, S.; Moschovis, K.; Katsarakis, N.; Kiriakidis, G. ZnO transparent thin films for gas sensor applications. Thin Solid Films 2006, 515, 551-554. [CrossRef]

41. Khan, Z.R.; Khan, M.S.; Zulfequar, M. Optical and Structural Properties of ZnO Thin Films Fabricated by Sol-Gel Method. Mater. Sci. Appl. 2011, 2, 340-345. [CrossRef]

42. Shakti, N.; Gupta, P. Structural and Optical Properties of Sol-gel Prepared ZnO Thin Film. Appl. Phys. Res. 2010, 2. [CrossRef]

43. Lee, J.; Sorescu, D.C.; Deng, X. Tunable Lattice Constant and Band Gap of Single- and Few-Layer ZnO. J. Phys. Chem. Lett. 2016, 7, 1335-1340. [CrossRef] 
44. Singh, S.; Thiyagarajan, P.; Mohan Kant, D.; Anita, D.; Thirupathiah, S.; Tiwari, B.; Kottaisamy, M.; Ramachandra Rao, M.S. Structure, microstructure and physical properties of $\mathrm{ZnO}$ based materials in various forms: Bulk, thin film and nano. Phys. D App. Phys. 2007, 40, 6312-6327. [CrossRef]

45. Chen, J.; Sun, K. Growth of vertically aligned ZnO nanorod arrays as antireflection layer on silicon solar cells. Sol. Energy Mater. Sol. Cells 2010, 94, 930-934. [CrossRef]

46. Nesheva, D.; Dzhurkov, V.; Stambolova, I.; Blaskov, V.; Bineva, I.; Moreno, J.M.C.; Preda, S.; Gartner, M.; Hristova-Vasileva, T.; Shipochka, M. Surface modification and chemical sensitivity of sol gel deposited nanocrystalline ZnO films. Mater. Chem. Phys. 2018, 209, 165-171. [CrossRef]

47. Taabouche, A.; Bouabellou, A.; Kermiche, F.; Hanini, F.; Sedrati, C.; Bouachiba, Y.; Benazzouz, C. Preparation and characterization of Al-doped $\mathrm{ZnO}$ piezoelectric thin films grown by pulsed laser deposition. Ceram. Int. 2016, 42, 6701-6706. [CrossRef]

48. Velázquez-Nevárez, G.A.; Vargas-García, J.R.; Aguilar-Hernández, J.; Vega-Becerra, O.E.; Chen, F.; Shen, Q.; Zhang, L. Optical and Electrical Properties of (002)-Oriented ZnO Films Prepared on Amorphous Substrates by Sol-Gel Spin-Coating. Mater. Res. 2016, 19, 113-117. [CrossRef]

49. Fitriana, F.; Septiani, N.L.W.; Irzaman, I.; Ferdiansjah, F.; Fahmi, M.Z.; Adhika, D.R.; Suyatman, S.; Nugraha, N.; Yuliarto, B. Preparation of (002)-oriented ZnO for CO gas sensor. Mater. Res. Express 2019, 6, 064003. [CrossRef]

50. Miranda, M.A.R.; Sasaki, J.M. The limit of application of the Scherrer equation. Acta Crystallogr. Acta Crystallogr. Sect. A Found. Crystallogr. 2018, A74, 54-65. [CrossRef]

51. Bindu, P.; Thomas, S. Estimation of lattice strain in ZnO nanoparticles: X-ray peak profile analysis. J. Theor. Appl. Phys. 2014, 8, 123-134. [CrossRef]

52. Suryanarayana, C.; Norton, M.G. X-ray Diffraction: A Practical Approach; Plenum Press Publishing: New York, NY, USA, 2013; pp. 3-19. [CrossRef]

53. Cai, H.; Shen, H.; Yin, Y.; Lu, L.; Shen, J.; Tang, Z. The effects of porous silicon on the crystalline properties of ZnO thin films. J. Phys. Chem. Solids 2009, 70, 967-971. [CrossRef]

54. Hur, T.-B.; Hwang, Y.-H.; Kim, H.-K.; Lee, I.J. Strain effects in ZnO thin films and nanoparticles. J. Appl. Phys. 2006, 99, 064308. [CrossRef]

55. Ghosh, R.; Basak, D.; Fujihara, S. Effect of substrate-induced strain on the structural, electrical, and optical properties of polycrystalline ZnO thin films. J. Appl. Phys. 2004, 96, 2689-2692. [CrossRef]

56. Bueno, C.; Pacio, M.; Osorio, E.; Perez, R.; Juarez, H. Effect of annealing atmosphere on optic-electric properties of ZnO thin films. Rev. Mex. Fis. 2017, 63, 569-574.

57. Xu, J.; Xue, Z.; Qin, N.; Cheng, Z.; Xiang, Q. The crystal facet-dependent gas sensing properties of ZnO nanosheets: Experimental and computational study. Sens. Actuators B Chem. 2017, 242, 148-157. [CrossRef]

58. Amakali, T.; Daniel, L.S.; Uahengo, V.; Dzade, N.Y.; De Leeuw, N.H. Structural and Optical Properties of ZnO Thin Films Prepared by Molecular Precursor and Sol-Gel Methods. Crystals 2020, 10, 132. [CrossRef]

59. Ramesh, M.; Nagaraja, H. Effect of current density on morphological, structural and optical properties of porous silicon. Mater. Today Chem. 2017, 3, 10-14. [CrossRef]

60. Rahmani, A.; Remache, L.; Guendouz, M.; Aida, M.S.; Hebboul, Z. Impact of the meso-PSi substrate on ZnO thin films deposited by spray pyrolysis technique for UV photodetectors. Appl. Phys. A 2021, 127, 1-10. [CrossRef]

61. Kumar, M.; Singh, B.; Yadav, P.; Bhatt, V.; Kumar, M.; Singh, K.; Abhyankar, A.; Kumar, A.; Yun, J.-H. Effect of structural defects, surface roughness on sensing properties of $\mathrm{Al}$ doped $\mathrm{ZnO}$ thin films deposited by chemical spray pyrolysis technique. Ceram. Int. 2016, 43, 3562-3568. [CrossRef]

62. Tsay, C.-Y.; Fan, K.-S.; Chen, S.-H.; Tsai, C.-H. Preparation and characterization of ZnO transparent semiconductor thin films by sol-gel method. J. Alloy. Compd. 2010, 495, 126-130. [CrossRef]

63. Salazar-Kuri, U.; Antúnez, E.; Estevez, J.; Olive-Méndez, S.F.; Silva-González, N.; Agarwal, V. Formation of different micromorphologies from VO 2 and ZnO crystallization using macro-porous silicon substrates. J. Phys. Chem. Solids 2016, $104,21-31$. [CrossRef] 